\title{
THEORETICAL AND EXPERIMENTAL INVESTIGATION OF THE EFFICIENCY OF THE USE OF HEAT-ACCUMULATING MATERIAL FOR HEAT SUPPLY SYSTEMS
}

\author{
Oleksandr Klymchuk \\ Department of Thermal Powel Plants and energy saving technologies, \\ Odessa National Polytechnic University \\ 1 Shevchenko ave., Odessa, Ukraine, 65044 \\ aaklymchuk@gmail.com \\ Alla Denysova \\ Department of Thermal Power Plants and Energy Saving Technologies \\ Odessa National Polytechnic University \\ 1 Shevchenko ave., Odessa, Ukraine, 65044 \\ alladenysova@gmail.com \\ Aleksandr Shramenko \\ Department of Thermal Powel Plants and Energy Saving Technologies \\ Odessa National Polytechnic University \\ 1 Shevchenko ave., Odessa, Ukraine, 65044 \\ alexandr.shramenko@gmail.com \\ Krystyna Borysenko \\ Department of Water Supply \\ Odessa State Academy of Civil Engineering and Architecture \\ 4 Didrihsona str., Odessa, Ukraine, 65029 \\ nefertichtvo@ukr.net \\ Lidiia Ivanova \\ Department of Thermal Powel Plants and Energy Saving Technologies \\ Odessa National Polytechnic University \\ 1 Shevchenko ave., Odessa, Ukraine, 65044 \\ leesoul18@gmail.com
}

\begin{abstract}
As a result of research, the conditions for the effective use of the volume of heat accumulator based on solid materials were determined. In the course of research, various schemes of the device of tubular heating elements for charging the channel elements of the heat accumulator were considered. Fire clay was used as a heat-accumulating material, capable of operating in a wide temperature range (up to $600{ }^{\circ} \mathrm{C}$ ). Mathematical modeling of temperature change in the process of discharge over the cross section of the heat-accumulating unit has been carried out. Mathematical modeling was carried out using an application package that allows to obtain the temperature distribution over the cross section of the heat accumulator at key points of its work. The obtained simulation results were tested on an experimental setup consisting of four heat-accumulating units during the charging process and during the discharge of the heat accumulator. According to the research results, the most effective layout of the heating elements was determined, which allows to make the most of the volume of the heat-accumulating material. The dependencies to determine the exponent and the averaging coefficient of the heat flux are also found, which allow a more rational use of the volume of the accumulating nozzle.

The research results can be used to reconstruct decentralized heat supply systems for both residential buildings and public buildings. This will significantly align the schedule of electricity consumption during the day and reduce the consumption of hydrocarbon fuels.

Keywords: heat supply system, heat accumulator, electric load schedule, non-stationary heat transfer, tubular heating elements.




\section{Introduction}

The urgency of the problem of energy saving is associated with a shortage of fuel and energy resources and man-made pollution of the environment. At the same time, the current state of Ukraine's energy sector requires a deep modernization of the existing energy blocks. Separately, it is worth noting the problem of uneven electricity consumption during the day with a pronounced failure of the load at night. This problem is not only in Ukraine, but also in several European countries. To reduce the need for building generating capacity, it is necessary to stimulate not only the conservation of electricity, but also the equalization of the load curve. This requires strengthening the differentiation of electricity tariffs for the end user by the time of day and encouraging the reduction of electricity consumption during peak consumption due to the transfer of consumption to another time of day $[1,2]$.

One of the ways to solve this issue may be the use of electricity at night rate for the needs of heating the house through the use of heat accumulators. Unlike electric accumulators, thermal accumulators have a much longer service life.

The rational choice of heat-accumulating materials and design parameters of the heat accumulator allows to increase the energy efficiency and reliability of the heat supply system [3, 4].

The process of charging the accumulator is mainly influenced by the thickness of the accumulating layer S of the nozzle and the location of the heating elements [5]. During seasonal heat accumulation, for example, from heliosystems, water [6] or soil [3] is usually used as a heat-accumulating material. And in the case of intermittent heating, provided by a combined heat supply system, when the temperature of the coolant is not more than $90{ }^{\circ} \mathrm{C}$, it is recommended to use water heat accumulators $[7,8]$.

The use of solid materials significantly reduces the amount of heat accumulator due to high operating temperatures and simplicity of design. And with a low power of the heat accumulator, it becomes possible to use it directly in a heated room [9].

To determine the rational design parameters of a solid-state accumulator, a mathematical model of thermal processes in the packing is needed. Currently, there are a number of analytical methods for solving heat conduction problems [10]. However, the obtained solutions are complex and have a rather cumbersome look. At the same time, in some cases, strict analytical solutions of problems cannot be obtained at all. For engineering calculations, simpler equations are needed, even at the expense of loss of solution accuracy.

In the case when the accumulating nozzle is a plate with a uniformly distributed heat flow, it is advisable to use the Semikin heat diagram method, which is the most common engineering method for calculating the heating of bodies outside with a constant heat flow [11]. When the heaters are located in the storage material, the heating occurs from the inside. For this case, under the boundary conditions of the second kind, this method does not allow determining the temperature distribution in the body correctly and is therefore subject to refinement.

To calculate the cooling process of the accumulating nozzle, it is advisable to use the theory of the Kondratiev regular thermal regime, which also needs to be refined for the case of cooling the material from the inside.

The aim of research is increasing the efficiency of heat accumulator based on solid materials for heat supply systems of buildings under various operating modes.

To achieve this aim it is necessary to solve the following objectives:

- supply the existing methods for calculating non-stationary heat transfer (Semikin method and the theory of the Kondratiev regular thermal regime) for the case of heat exchange inside the material;

- conduct experimental studies of the accumulator heat to confirm theoretical studies.

\section{Materials and methods of research}

According to the Semikin thermal diagram method, the whole process of heating and cooling the body is divided into two stages:

- the first (inertial period) corresponds to the penetration of heat into the thickness of the body;

- the second takes into account the change in the distribution of body temperature throughout the volume simultaneously. 
In both cases, the temperature distribution curve in the accumulating nozzle is described by an nth order parabola. The type of the parabola equation does not depend on the direction of the heat flow, i.e. true for cases of heating and cooling the body.

It has been established that, in accordance with the principle of heat flow stability, the shape of the heating surface affects the temperature distribution in the body only near this surface [11]. At a sufficient distance from the surface, the shape of the temperature field will depend on the direction of propagation of the heat flux in the body.

For the first stage of the heating process, the parabola equation is:

$$
t=\left(t_{n}-t_{o}\right) \cdot\left(\frac{y}{x}\right)^{n}+t_{o},
$$

where $\mathrm{t}$ - the current body temperature, ${ }^{\circ} \mathrm{C} ; \mathrm{t}_{\mathrm{n}}$ - the temperature on the inner surface of the body, ${ }^{\circ} \mathrm{C}$; $\mathrm{t}_{0}$ - the initial temperature of the body at a distance $\mathrm{X}$ from the surface, ${ }^{\circ} \mathrm{C} ; \mathrm{y}$ - coordinate, measured in the direction from the surface of the body to a point located at a distance $\mathrm{X}, \mathrm{m}$.

If the body from the outside is limited to a cylindrical surface and is thermally insulated, then for the second heating stage, the equation for the temperature curve is written as follows:

$$
\mathrm{t}=\left(\mathrm{t}_{\mathrm{n}}-\mathrm{t}_{\mathrm{os}}\right) \cdot\left(\frac{\mathrm{z}}{\mathrm{X}}\right)^{\mathrm{n}}+\mathrm{t}_{\mathrm{os}},
$$

where $\mathrm{t}_{\mathrm{os}}$ - the temperature of the outer surface of the body, ${ }^{\circ} \mathrm{C} ; \mathrm{z}$ - coordinate, measured from the outer surface of the body, $\mathrm{m}$.

The end of the first and the beginning of the second stage begins at the moment when the depth of the layer warm-up becomes equal to the layer thickness.

Of particular importance in equations (1) and (2) is the exponent $n$. Using this value, it is possible in each specific case to ensure that the solution obtained has a given accuracy.

Equation (1) can be represented in a dimensionless form:

$$
\frac{\mathrm{t}-\mathrm{t}_{\mathrm{o}}}{\left(\mathrm{t}_{\mathrm{n}}-\mathrm{t}_{\mathrm{o}}\right)}=\left(\frac{\mathrm{y}}{\mathrm{X}}\right)^{\mathrm{n}} \text {. }
$$

In view of the notation $\vartheta=\mathrm{t}_{\mathrm{n}}-\mathrm{t}$ and $\vartheta_{0}=\mathrm{t}_{\mathrm{n}}-\mathrm{t}_{0}$, let's obtain:

$$
\Theta=\frac{\vartheta}{\vartheta_{0}}=1-\left(\frac{\mathrm{y}}{\mathrm{X}}\right)^{\mathrm{n}} .
$$

If in equation (1) the coordinate $y$, which is measured from the top of the parabola, is replaced by the coordinate $\mathrm{x}$, which is measured from the surface of the body, then the equation of the temperature curve will be:

$$
t=\left(t_{n}-t_{o}\right) \cdot\left(1-\frac{x}{x}\right)^{n}+t_{o}
$$

Equation (5) can be represented in the criterial form:

$$
\Theta=\frac{\mathrm{t}_{\mathrm{n}}-\mathrm{t}}{\left(\mathrm{t}_{\mathrm{n}}-\mathrm{t}_{\mathrm{o}}\right)}=1-\left(1-\frac{\delta}{\Delta}\right)^{\mathrm{n}},
$$

where $X_{0}$ - the characteristic size of the body - the radius of the heating surface; $\delta=\frac{x}{X_{0}}-$ relative coordinate of a point; $\Delta=\frac{\mathrm{X}}{\mathrm{X}_{0}}-$ relative thickness of the layer accumulating nozzles. 
Under the boundary conditions of the second kind (with a stable heat flux to the surface), the equation of the Fourier law has the form [12]:

$$
\mathrm{q}_{\mathrm{s}}=-\lambda\left(\frac{\partial \mathrm{t}}{\partial \mathrm{y}}\right)_{\mathrm{n}}=\lambda \cdot \mathrm{k} \frac{\mathrm{t}_{\mathrm{n}}-\mathrm{t}_{\mathrm{o}}}{\mathrm{X}}=\mathrm{const}
$$

where $\mathrm{q}_{\mathrm{s}}$ - the specific heat flux to the body surface, $\mathrm{W} / \mathrm{m}^{2} ; \lambda$ - coefficient of thermal conductivity of the material, $\mathrm{W} /(\mathrm{mK}) ; \mathrm{k}$ - coefficient of proportionality.

The temperature difference $\left(t_{n}-t_{0}\right)$, which is included in equation (7), can be represented as:

$$
\mathrm{t}_{\mathrm{n}}-\mathrm{t}_{\mathrm{o}}=\frac{1}{\mathrm{k}} \cdot \frac{\mathrm{q}}{\lambda} \mathrm{X}
$$

After substituting equation (7) into equation (8), let's obtain the relation for calculating the current temperature of the layer of the accumulating nozzle:

$$
\mathrm{t}=\frac{1}{\mathrm{k}} \cdot \frac{\mathrm{q}}{\lambda} \frac{\mathrm{y}^{\mathrm{n}}}{\mathrm{X}^{\mathrm{n}-1}}+\mathrm{t}_{0}
$$

or

$$
\mathrm{t}=\frac{1}{\mathrm{k}} \cdot \frac{\mathrm{q}}{\lambda} \frac{(\mathrm{X}-\mathrm{x})^{\mathrm{n}}}{\mathrm{X}^{\mathrm{n}-1}}+\mathrm{t}_{0} .
$$

After conversion, let's obtain the equation for finding the temperature in the cross section of the cylindrical nozzle layer at a distance $\mathrm{x}$ from the surface:

$$
\mathrm{t}=\frac{1}{\mathrm{k}} \cdot \frac{\mathrm{q}}{\lambda} \frac{(\mathrm{X}-\mathrm{x})^{\mathrm{n}}}{\mathrm{X}^{\mathrm{n}-1}}+\mathrm{t}_{0}
$$

In the criterial form, the relation (11) looks as follows:

$$
\Theta=\frac{\mathrm{t}_{\mathrm{n}}-\mathrm{t}}{\mathrm{t}_{\mathrm{n}}-\mathrm{t}}=1-\frac{1}{\mathrm{k}} \mathrm{Ki} \Delta\left(1-\frac{\delta}{\Delta}\right)^{\mathrm{n}},
$$

where $\mathrm{Ki}=\frac{\mathrm{qX}_{\mathrm{o}}}{\lambda\left(\mathrm{t}_{\mathrm{n}}-\mathrm{t}_{\mathrm{o}}\right)}-$ Kirpichev criterion.

The average temperature of the heated layer:

$$
\mathrm{t}_{\mathrm{av}}-\mathrm{t}_{0}=\frac{\int_{0}^{\mathrm{x}}\left(\mathrm{t}-\mathrm{t}_{0}\right) \mathrm{d} v}{\int_{0}^{\mathrm{x}} \mathrm{d} v}
$$

where $\mathrm{d} v=2 \pi\left(\mathrm{X}_{0}+\mathrm{X}-\mathrm{y}\right) 1 \mathrm{dy}-$ the elementary volume; $l$ - body length, $\mathrm{m}$

Then the average body temperature:

$$
t_{a v}-t_{o}=\frac{\int_{0}^{x}\left(t_{n}-t_{0}\right)\left(\frac{y}{x}\right)^{n} 2 \pi\left(x_{o}+X-y\right) l d y}{\int_{0}^{x} 2 \pi\left(X_{o}+X-y\right) l d y}=\frac{1}{n+1}\left(t_{n}-t_{o}\right) \frac{1+\frac{1}{n+2} \Delta}{1+\frac{1}{2} \Delta},
$$

Thus, to describe the temperature field in the cylindrical layer of the accumulating nozzle when heated with a constant heat flux from the inside, the equation is used:

$$
\mathrm{t}=\mathrm{t}_{0}+\Delta \mathrm{t} \cdot\left(1-\frac{\mathrm{x}}{\mathrm{X}}\right)^{\mathrm{n}} \text {. }
$$


The magnitude of the temperature difference can be calculated by the equation:

$$
\Delta \mathrm{t}=\frac{\mathrm{q}_{\mathrm{s}} \cdot \mathrm{X}}{\mathrm{k} \cdot \lambda}
$$

In equations (15) and (16), the determining factors are the exponent $\mathrm{n}$ and the coefficient of averaging of the heat flux $\mathrm{k}$. In the Semikin thermal diagram method, their value is determined only for the case of heating the material outside. Therefore, for the case of heating from the inside, a numerical simulation of the nozzle heating over the cross section was performed using a specialized software package that uses well-known methods for the numerical solution of unsteady heat conduction problems [13-15]. As a result, for the first time, dependence has been established for determining the averaging coefficient of the heat flux $\mathrm{k}$ for the case of heating from inside the cylindrical nozzle layer under boundary conditions of the second kind.

The model is a cylinder with an outer radius $\mathrm{R}$, in the center of which there is a cylindrical cavity with radius r. On the surface of the cylindrical cavity receives a constant heat flow Q (Fig. 1).

The material of the cylinder is chromomagnesite. The outer radius of the cylinder changed and was $\mathrm{R}=15 ; 20$; thirty; 50; 100; and $150 \mathrm{~mm}$. The radius of the internal cylindrical cavity was constant and equal to $\mathrm{r}=5 \mathrm{~mm}$. The simulation was carried out for cases with different specific heat flux to the surface.

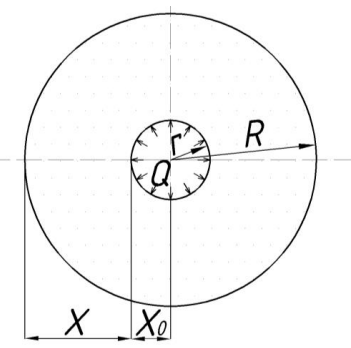

Fig. 1. General view of the model

The value of the coefficient of the shape of the body averaging heat flux is determined from the resulting temperature difference

$$
\mathrm{k}=\frac{\mathrm{q} \cdot \mathrm{X}}{\lambda \cdot \Delta \mathrm{t}}
$$

For the interval of the ratio of the outer radius to the inner $4 \leq \mathrm{R} / \mathrm{r}<30$ dependence $k=f(R / r)$ is a regression equation of the form $k=0,262 \cdot R / r+2$. The plot of the averaging coefficient of the heat flux as a function of the relative radius $(\mathrm{R} / \mathrm{r})$ is shown in Fig. 2.



Fig. 2. Graph of the dependence of averaging coefficient of the heat flux on the relative radius 
In a similar way, the dependence $n=f(\Delta)$ presented in Fig. 3.

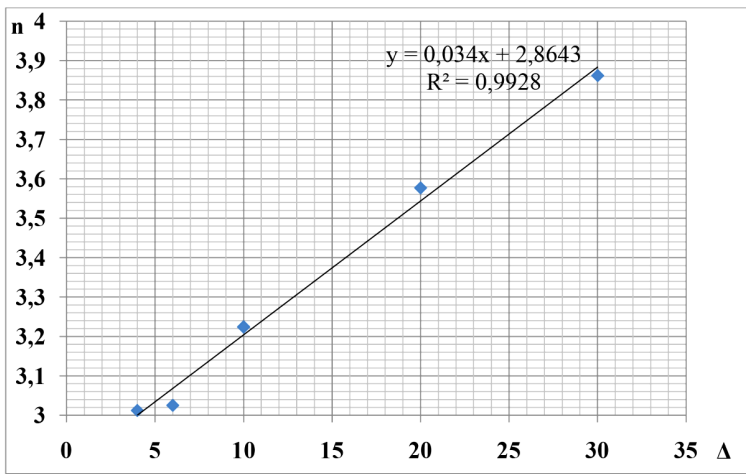

Fig. 3. Graph of the dependence of the exponent $n$ on the relative thickness of the heating

An experimental study of the processes of charging and discharging the heat of the accumulator was performed on a pilot plant. The heat accumulator consists of two channels formed by solid-state nozzles (Fig. 4, 5). The study of the dynamics of the processes of heating and cooling of a solid-state accumulating nozzle was performed using chromel-copel and chromel-alumel thermocouples installed at characteristic points of the heat accumulator. Thermocouples 1-7 are located in the central section of the accumulating nozzle, thermocouple 8 - at a distance of $345 \mathrm{~mm}$ from thermocouple 5 along the air path. Data from thermocouples are recorded and recorded on a computer using a universal eight-channel meter-regulator TPM 138 of the OWEN company and special software Owen Process Manager.

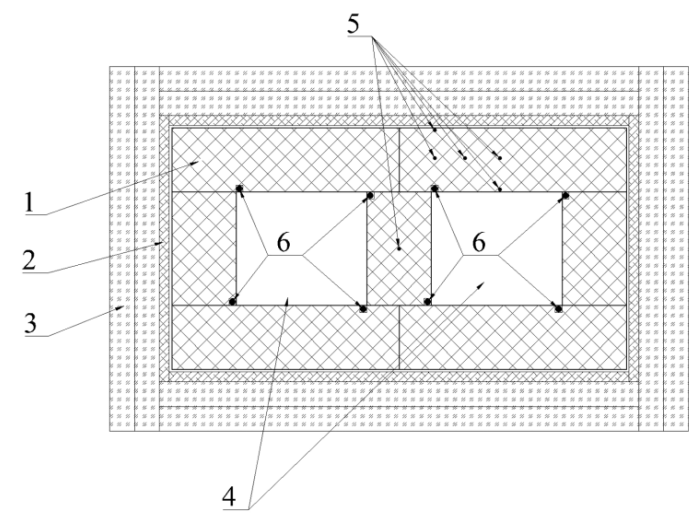

Fig. 4. Heat accumulator cross-section: 1 - fireclay brick; 2 - magnesite plate; 3 - mineral wool; 4 - channel for the passage of air; 5 - thermocouple locations; 6 - heating elements

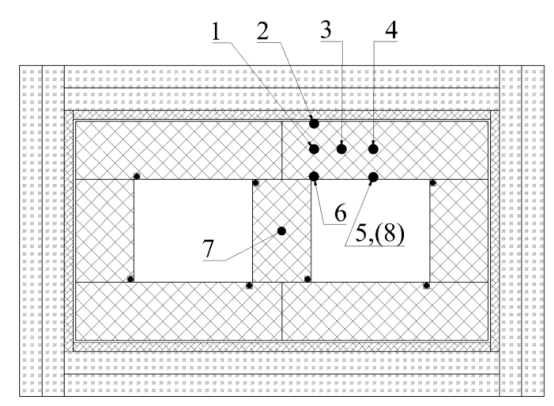

Fig. 5. The location of thermocouples in the accumulating material: 1 - thermocouple $1(\mathrm{CA}(\mathrm{K}))$; 2 - thermocouple $2(\mathrm{CC}(\mathrm{L})) ; 3$ - thermocouple $3(\mathrm{CA}(\mathrm{K})) ; 4$ - thermocouple $4(\mathrm{CA}(\mathrm{K}))$; 5 - thermocouple $5(\mathrm{CA}(\mathrm{K})) ; 6$ - thermocouple $6(\mathrm{CA}(\mathrm{K})) ; 7$ - thermocouple $7(\mathrm{CA}(\mathrm{K}))$; 8 - thermocouple $8(\mathrm{CC}(\mathrm{L}))$ 
For heating the accumulating nozzle, direct heating elements of stainless steel 12X18H10T are used. Power of 1 heating element makes $625 \mathrm{~W}$, total power $-5 \mathrm{~kW}$. To adjust the power of the heating elements, thyristor controllers are installed (one controller for two heating elements). The five main modes of charging and discharging heat from the accumulator with natural and forced convection are considered. For each of these modes, a series of five experiments was performed.

\section{The results of experimental studies of the cooling dynamics of the accumulating nozzle}

An analysis of the experimental results allows to obtain data on the nature of the distribution and the characteristics of the temperature change at various points of the accumulating nozzle.

Based on the experimental data, it is established:

- natural logarithms of the excess temperature when heated and the cooled material of the nozzle change according to a linear law (Fig. 6);

- process of cooling and heating of the accumulating nozzle can be divided in time into two stages: the stage of the disordered (irregular) process and the stage of the regular mode.

Such a character of temperature change in the body is characteristic of processes traditionally described by the theory of the Kondratiev regular thermal regime.

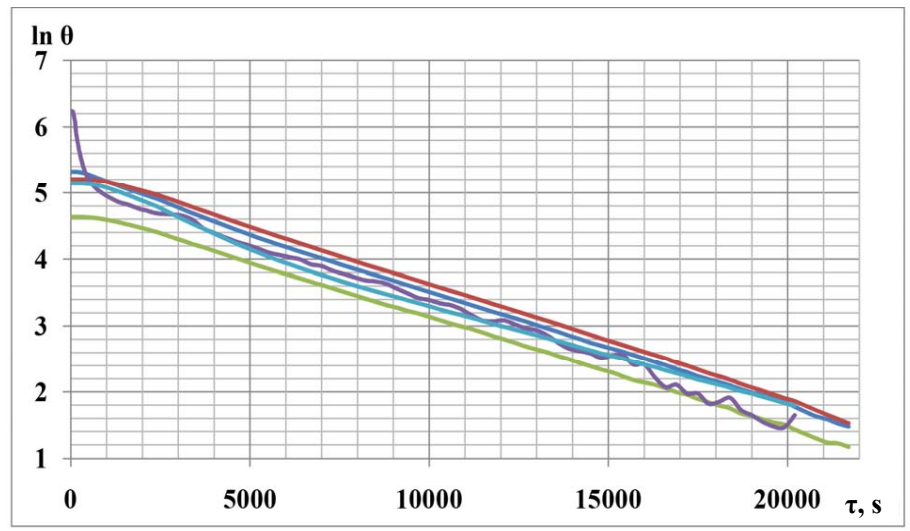

Fig. 6. Graph of changes in the logarithm of the excess temperature during the cooling of the nozzle: $1-6$ - thermocouple numbers

According to the third Kondratiev theorem, at an increase in the heat transfer coefficient, the cooling rate tends to a finite limit:

$$
\lim _{\alpha \rightarrow \infty} \mathrm{m}=\mathrm{m}_{\infty},
$$

which is proportional to the coefficient of thermal diffusivity:

$$
\mathrm{a}=\mathrm{Km}_{\infty}
$$

where the coefficient of proportionality K depends only on the shape and size of the body, has the dimension of the area and therefore is called the coefficient of the shape of the body. The cooling rate, in this case, is determined by the equation:

$$
\mathrm{m}=\frac{\ln \vartheta^{\prime}-\ln \vartheta^{\prime \prime}}{\tau^{\prime \prime}-\tau^{\prime}}
$$

where $\theta$ ' and $\theta$ ' - excess body temperatures at arbitrary times $\tau$ ' and $\tau$ '”.

Thus, the obtained experimental results allow to conclude that the Kondratiev theory of the regular thermal regime can be used to describe the accumulation and return of heat from the accumulator. On the basis of experimental data, the numerical value of the body shape 
coefficient $\mathrm{K}$ was calculated, which is used in this theory to determine the rate of cooling and heating of bodies.

\section{Discussion of the research results of the effectiveness of the heat-accumulating nozzle}

Theoretical and experimental studies of unsteady heat conduction make it possible to supplement the Semikin method for the case of heating from within under boundary conditions of the second kind. The dependences for determining the exponent $\mathrm{n}(15)$ and the averaging coefficient of the heat flux $\mathrm{k}(16)$ are found.

Previously it was assumed that the temperature distribution in the body is described by a parabola (i. e., $n=2$ ). However, as is shown, for the case of heating from the inside this is not the case (Fig. 3). The obtained data, as a result, make it possible to more accurately determine the distribution of heat in the accumulating nozzle, which is very important when choosing the distance between the heating elements.

However, the found value for determining the coefficient of averaging the heat flux $\mathrm{k}(16)$, which is used in calculating the temperature difference over the cross section of the accumulating nozzle during heating for heating conditions from the inside by a constant heat flux, is of fundamental importance in the obtained results. Previously, its definition was possible only for the case of heating by heat flow from outside.

Based on experimental data, it is shown that to describe the dynamics of the process of heating and cooling the accumulating nozzle, it is permissible to use the well-known and proven theory of the Kondratiev regular thermal regime. It is supplemented with a shape factor for the case of forced convection in the channels inside the body.

It should be noted that in the work processes of charging and discharging the accumulator are considered separately from each other. However, in this mode, storage devices do not always work. There are cases when the supply and removal of heat occur simultaneously. These questions require further detailed research.

\section{Conclusions}

According to the research results of non-stationary heat conduction, the Semikin method was supplemented for the case of heating from the inside under the boundary conditions of the second kind. The dependences for determining the exponent $\mathrm{n}(15)$ are found, as well as the relationship for determining the averaging coefficient of heat flux $\mathrm{k}$ (16), which is used in calculating the temperature difference over the cross section of the accumulating nozzle during heating for heating conditions from the inside by constant heat flux.

On the basis of the obtained data, the theory of the Kondratiev regular thermal regime is supplemented by the shape factor for the case of forced convection in the channels inside the body.

The obtained data, as a result, make it possible to more accurately determine the distribution of heat in the accumulating nozzle, which is very important when choosing the distance between the heating elements.

\section{References}

[1] Enerhetychna stratehiya ukrainy na period do 2035 roku «Bezpeka, enerhoefektyvnist, konkurentospromozhnist» (2015). Verkhovna Rada Ukrainy. Kyiv, 66.

[2] Bozhko, V. M., Gromadskiy, Yu. S., Krukovskiy, P. G., Timchenko, N. P., Rozinskiy, D. I. (2001). Sovremennoe sostoyanie i perspektivy razvitiya elektrootopleniya v Ukraine. Promislova elektroenergetika ta elektrotekhnika, 3, 18-21.

[3] Himenko, A. V., Tarasova, V. A. (2013). Issledovanie rezhimov raboty elektricheskogo teplovogo akkumulyatora. Intehrovani tekhnolohiyi ta enerhozberezhennia, 2, 136-139.

[4] Nedbaylo, A. N. (2004). Eksperimental'naya ustanovka po issledovaniyu gruntovogo akkumulyatora teploty. Promyshlennaya energetika, 26 (6), 182-185.

[5] Sotnikova, O. A., Turbin, B. C., Grigor'ev, V. A. (2003). Akkumulyatory teploty teplogeneriruyuschih ustanovok sistem teplosnabzheniya. Zhurnal «AVOK», 5, 40-44. 
[6] Mazurenko, A. S., Klimchuk, A. A., Yurkovskiy, S. Yu., Omeko, R. V. (2015). Development of the scheme of combined heating system using seasonal storage of heat from solar plants. EasternEuropean Journal of Enterprise Technologies, 1 (8 (73)), 15-20. doi: https://doi.org/10.15587/1729-4061. 2015.36902

[7] Mazurenko, A., Denysova, A., Balasanian, G., Klymchuk, O., Tsurkan, A. (2018). Construction of methods to improve operational efficiency of an intermittent heat supply system by determining conditions to employ a standby heating mode. Eastern-European Journal of Enterprise Technologies, 6 (8 (96)), 25-31. doi: https://doi.org/10.15587/1729-4061.2018.148049

[8] Macevityy, Yu. M., Ganzha, N. G., Himenko, A. V. (2011). Ocenka energeticheskoy effektivnosti sistem teploakkumulyacionnogo otopleniya administrativnyh zdaniy. Energosberezhenie, energetika, audit, 10, 9-16.

[9] Mazurenko, A., Denysova, A., Balasanian, G., Klimchuk, A., Borysenko, K. (2017). Improving the operation modes efficiency in heat pump systems of hot water supply with the two-stage heat accumulation. Eastern-European Journal of Enterprise Technologies, 1 (8 (85)), 27-33. doi: https://doi.org/10.15587/17294061.2017.92495

[10] Patankar, S. V.; Yan'kov, G. G. (Ed.) (2003). Chislennoe reshenie zadach teploprovodnosti i konvektivnogo teploobmena pri techenii v kanalah. Moscow: Izdatel'stvo MEI, 312.

[11] Evtyukova, I. P., Kacevich, L. S., Nekrasova, N. M., Svenchanskiy, A. D.; Svenchanskiy, A. D. (Ed.) (1982). Elektrotekhnologicheskie promyshlennye ustanovki. Moscow: Energoizdat, 400.

[12] Egorov, V. I. (2006). Tochnye metody resheniya zadach teploprovodnosti. Sankt-Peterburg: SPb GU ITMO, 48.

[13] Gallager, R. (1984). Metod konechnyh elementov. Osnovy. Moscow: Mir, 428.

[14] Wu, C., Nikulshin, V. (2000). Method of thermoeconomical optimization of energy intensive systems with linear structure on graphs. International Journal of Energy Research, 24 (7), 615-623. doi: https://doi.org/10.1002/1099-114x(20000610)24:7<615::aid-er608>3.0.co;2-p

[15] Ganzha, A. M., Zaiets, O. M., Marchenko, N. A., Kollarov, O. Ju., Njemcev, E. M. (2018). Methodology of calculation of multiplex heat exchang apparatus with cross flow and mixing in heat carriers. Journal of new technologies in environmental science, 2 (1), 26-35. 